Article

\title{
Characterizing Post-Drainage Succession in Thermokarst Lake Basins on the Seward Peninsula, Alaska with TerraSAR-X Backscatter and Landsat-based NDVI Data
}

\author{
Prajna Regmi $^{1, *}$, Guido Grosse ${ }^{1}$, Miriam C. Jones ${ }^{2,3}$, Benjamin M. Jones ${ }^{4}$ \\ and Katey Walter Anthony ${ }^{3}$
}

1 Geophysical Institute, University of Alaska Fairbanks, Fairbanks, AK 99775, USA;

E-Mail: ggrosse@gi.alaska.edu

2 Eastern Geology and Paleoclimate Center, US Geological Survey, Reston, VA 20192, USA;

E-Mail: miriamjones@usgs.gov

3 Water and Environmental Research Center, University of Alaska, Fairbanks, AK 99775, USA;

E-Mail: kmwalteranthony@alaska.edu

4 Alaska Science Center, US Geological Survey, Anchorage, AK 99508, USA;

E-Mail: bjones@usgs.gov

* Author to whom correspondence should be addressed; E-Mail: pregmi@alaska.edu;

Tel.: +1-907-474-7184; Fax: +1-907-474-7290.

Received: 15 September 2012; in revised form: 10 November 2012 / Accepted: 16 November 2012 / Published: 27 November 2012

\begin{abstract}
Drained thermokarst lake basins accumulate significant amounts of soil organic carbon in the form of peat, which is of interest to understanding carbon cycling and climate change feedbacks associated with thermokarst in the Arctic. Remote sensing is a tool useful for understanding temporal and spatial dynamics of drained basins. In this study, we tested the application of high-resolution X-band Synthetic Aperture Radar (SAR) data of the German TerraSAR-X satellite from the 2009 growing season (July-September) for characterizing drained thermokarst lake basins of various age in the ice-rich permafrost region of the northern Seward Peninsula, Alaska. To enhance interpretation of patterns identified in X-band SAR for these basins, we also analyzed the Normalized Difference Vegetation Index (NDVI) calculated from a Landsat-5 Thematic Mapper image acquired on July 2009 and compared both X-band SAR and NDVI data with observations of basin age. We found significant logarithmic relationships between (a) TerraSAR-X backscatter and basin age from 0 to 10,000 years, (b) Landat-5 TM NDVI and basin age from 0 to 10,000 years, and (c) TerraSAR-X backscatter and basin age from 50 to 10,000 years.
\end{abstract}


NDVI was a better indicator of basin age over a period of $0-10,000$ years. However, TerraSAR-X data performed much better for discriminating radiocarbon-dated basins (50-10,000 years old). No clear relationships were found for either backscatter or NDVI and basin age from 0 to 50 years. We attribute the decreasing trend of backscatter and NDVI with increasing basin age to post-drainage changes in the basin surface. Such changes include succession in vegetation, soils, hydrology, and renewed permafrost aggradation, ground ice accumulation and localized frost heave. Results of this study show the potential application of X-band SAR data in combination with NDVI data to map long-term succession dynamics of drained thermokarst lake basins.

Keywords: thermokarst lake; drained thermokarst lake basin; X-band SAR; arctic peatland succession; permafrost; land surface age determination

\section{Introduction}

Thermokarst lakes and drained thermokarst lake basins (DTLBs) are important indicators of permafrost and thermokarst dynamics in arctic and subarctic lowlands with ice-rich permafrost [1-5]. In Alaska, they occupy a large portion of the Arctic Coastal Plain, the Arctic Foothills and the Seward Peninsula [6-8], forming a complex and dynamic landscape with repeated cycles of lake formation and drainage due to permafrost degradation and aggradation [9-11]. Moreover, DTLBs accumulate soil organic carbon (SOC) in the form of peat, which has important implications for northern SOC pool distribution and high-latitude carbon cycling $[10,12,13]$.

Recent attention has focused on the effect of projected climate warming on the rate of microbial decomposition of SOC stored in northern permafrost and peatland regions that will have an impact on greenhouse gas release to the atmosphere [14-17]. Under warming conditions, northern SOC pools have the potential for large emissions of methane $\left(\mathrm{CH}_{4}\right)$ or carbon dioxide $\left(\mathrm{CO}_{2}\right)$, depending on the soil aerobic regime, due to an enhanced rate of microbial decomposition of organic matter that will serve as a positive feedback to climate warming $[17,18]$. However, the amount of carbon sequestered in DTLBs and its role for the carbon budget in permafrost regions in a warming scenario is yet to be quantified for the Arctic.

Jones et al. [10] and Hinkel et al. [12] demonstrated that basin age can be used to estimate peat thickness and accumulation rates in DTLBs. Long-term dynamics of DTLBs are characterized by post-drainage changes in vegetation, surface hydrology, soils characteristics and often permafrost aggradation, following a relatively predictable pattern reflecting successional stage or the relative age of the drained basin $[9,10,12,19,21]$. Important processes that shape the evolution of thermokarst lakes and DTLBs include permafrost thaw, ground subsidence and related erosion, ponding, surface and subsurface lake drainage, as well as post-drainage ground ice accumulation and frost heave [5,20,21]. Various models of a "thaw-lake cycle" were proposed to explain the geomorphic processes of origin and drainage of thermokarst lakes [21-24]. The cycle may begin with formation of ponds at the intersection of ice-wedge troughs and in low-center polygons, which upon continued permafrost thaw, eventually coalesce and enlarge to small lakes. As a result of thermo-mechanical shore erosion and 
thaw slumping, lake dimensions increase over time, both radially and in depth depending on the excess ice content of the permafrost [25-27]. A first cycle is ended when lake drainage is triggered by stream piracy, tapping, bank overflow or ice-wedge erosion [22,28]. In thin discontinuous permafrost, thermokarst lakes may drain internally through open taliks [20]. Following drainage, re-vegetation and peat accumulation begins in drained basins $[10,19,29,30]$. Wet, graminoid vegetation is established in recently drained basins in 5-10 years, and peat accumulation starts in the first 20-100 years since drainage [10]. As a result of exposing the lake bottom, cold winter frost can penetrate into the ground, and new permafrost aggradation begins in the drained lake basin [31]. Additionally, over time, basin productivity decreases as wet graminoid vegetation communities, including productive grass (Calamagrostis and Dupontia) and sedge fens (Carex aquatilis), are replaced by ericaceous bog and tussock-dominated ecosystems. Zona et al. [32] have shown very high Gross Primary Productivity (GPP) for graminoid vegetation of younger DTLBs compared to the vegetation community of older DTLBs in Arctic ecosystems. This vegetative succession occurs as nutrients from the fresh lake sediments are consumed, permafrost aggradation causes limitations in rooting depth and liquid water availability, and ground ice formation and frost heave result in surface drying [10,32]. Over time, low-centered ice wedge polygons start to develop in drained basins, indicating the accumulation of massive ground ice bodies [33], which eventually creates preconditions for new ponding and the beginning of a new thermokarst lake cycle [12].

Previously, the thermokarst lake cycle was assumed to have a duration of 2,000-3,000 years in some regions of northwestern Alaska [8,34], but recent studies show that some drained basins older than 5,000 years before present (BP) persisted as basins without redeveloping into a lake [12]. Also, mechanisms associated with ground ice dynamics in the thermokarst lake cycle have remained controversial, and the hypothesis that thermokarst lakes evolve in a direct cyclic order has been questioned for the northern Alaskan Coastal Plain [21]. For the northern Seward Peninsula, Jones et al. [10] and Kessler et al. [35] demonstrated that frequency and timing of a thermokarst lake cycle depends on local factors, such as topography, ground ice content and distribution with depth, climate and the geomorphology and history of lake/basin configurations. A recent study has also found that thermokarst lake "cycling" often is not based on formation of new lakes in a DTLB, but linked to erosion from neighboring lakes that preferentially expand into the low banks of DTLB [27].

Understanding the temporal and spatial dynamics of DTLBs requires substantial geological, cryolithological and geochronological groundwork in remote regions of the Arctic. Application of remote sensing methods to map drained lake basins and their surface properties is a critical component in upscaling such field results to larger regions. In the past, a number of studies have exploited moderate and low resolution satellite images derived from optical sensors to map DTLBs, evaluate their spatial and temporal dynamics, as well as classify their relative age, relying on relationships of land surface properties to post-drainage succession in vegetation, soils and permafrost aggradation $[9,10,12,36]$. Hinkel et al. [12] utilized Landsat-7 Enhanced Thematic Mapper Plus (ETM+) imagery to study the spatial extent of DTLBs and classify their relative age on the Barrow Peninsula, Alaska. For age-classification, they established a relationship between radiocarbon-dated surface peat and spectral and textural properties of basins, determined by factors such as vegetation type, degree of ponding and ice wedge polygon development, basin wetness and texture. Zulueta et al. [36] used Moderate Resolution Imaging Spectroradiometer (MODIS) data to link aircraft-based $\mathrm{CO}_{2}$ flux estimates with 
NDVI of DTLBs at different successional stages for the same region. Jones et al. [10] used Landsat-5 Thematic Mapper (TM) based Normalized Differential Vegetation Index (NDVI), as well as Minimum Noise Fraction (MNF), to estimate carbon stocks stored in the uppermost peat deposits $(\sim 50-60 \mathrm{~cm})$ of DTLBs of the northern Seward Peninsula, Alaska. However, remote sensing data derived from optical sensors is generally limited to surface conditions and do not penetrate into the soil. Hence, optical remote sensing data does not reveal much information about soil moisture conditions, which should be a good indicator of basin successional stage, particularly centuries after drainage, when basin vegetation succession slows down. SAR remote sensing data has been frequently used to detect soil surface moisture due to its sensitivity to soil's dielectric constant [37-40]. In addition, SAR sensors also have advantage over optical remote sensing in Arctic regions, as they can image the Earth's surface in all weather conditions and at any time of the day.

In this study, we investigated the application of high resolution X-band SAR data of the German TerraSAR-X (TSX) satellite for determining the time since lake drainage (or drained basin age) based on basin surface properties and to understand the post-drainage succession dynamics for a set of DTLBs. Contrary to most previous studies that investigated post-drainage succession patterns of DTLBs on the Alaska Arctic Coastal Plain, we here study DTLBs located in the ice-rich permafrost region of the northern Seward Peninsula, Alaska, where mean annual ground and mean annual air temperatures are warmer than in the Arctic Coastal Plain, and where yedoma permafrost and its large soil carbon pool are particularly vulnerable to climate change. This allows an interesting comparison of basin succession patterns across a permafrost and climate gradient.

In the context of radar applications, backscatter at short wavelengths, such as X-band, in vegetated areas is largely dominated by scattering processes in the crown layer of branches and foliage of the canopy and is less sensitive to background properties, such as soil moisture content, while soil moisture will have greater influence on backscatter in the case of exposed soil surface or ground with a thin layer of vegetation [41]. But, the retrieved signal in areas of sparse vegetation corresponds to combined signatures of vegetation and ground properties. The backscatter from vegetation canopies is also affected by many factors, including plant moisture content, size, shape and orientation and distribution of the scatters in a canopy with respect to the sensor's viewing angle [41]. We also utilized NDVI derived from Landsat-5 TM to aid in the interpretation of basin backscatter signal and the understanding of vegetation succession dynamics in DTLBs. NDVI is sensitive to plant biomass and can be useful to differentiate tundra vegetation type [42] in DTLBs at various stages $[32,36]$. This further helps to identify major biophysical parameters that are influencing basin backscatter. To compare TSX backscatter data with basin age, we used a set of 14 basins that were previously radiocarbon-dated by Jones et al. [10], as well as 60 drained basins identified in aerial and satellite images acquired during 1950-2010 [43].

\section{Study Area}

This study was conducted for an area of approximately $3,800 \mathrm{~km}^{2}$ on the northern Seward Peninsula, Alaska $\left(66.5^{\circ} \mathrm{N}, 164.5^{\circ} \mathrm{W}\right.$; Figure 1). The study area is situated in an ice-rich permafrost region and is largely covered by thermokarst-affected terrain with a large number of thermokarst lakes and DTLBs and erosional remnants of uplands. The northern Seward Peninsula is identified as one of 
the major lake districts of Alaska, where $7 \%$ of the $6,418 \mathrm{~km}^{2}$ coastal lowland area is covered with lakes larger than 1 hectare [44] (Figure 1). Thermokarst lakes in the lowland plain of the region mainly formed as a result of permafrost degradation due to warming throughout the Holocene $[8,45]$. Currently, the mean annual ground temperature is recorded as $\sim-3{ }^{\circ} \mathrm{C}$ [46]. This allows for current formation of permafrost and epigenetic ice wedges following drainage of thermokarst lakes in the region [47]. The depth of permafrost exceeds $90 \mathrm{~m}$ [47] and the active layer is $0.3-0.6 \mathrm{~m}$ thick [25]. The permafrost thickness very likely varies due to the distribution and thermal impact of thermokarst lakes [46,48]. However, detailed data on permafrost distribution and thickness is not available for the Seward Peninsula.

Figure 1. Digital Elevation Model (DEM) base map of the Seward Peninsula showing the location of lakes ( $>1$ ha) mapped in National Hydrography Dataset (NHD) and DTLBs that drained ( $>90 \%$ of surface area loss) $0-50$ years ago (based on times series analysis of aerial and satellite images from 1950 to 2010 [43]) and 50-10,000 years BP (based on radiocarbon dating [10]). The footprints of six TerraSAR-X scenes used in analysis are outlined in blue with their respective acquisition dates.

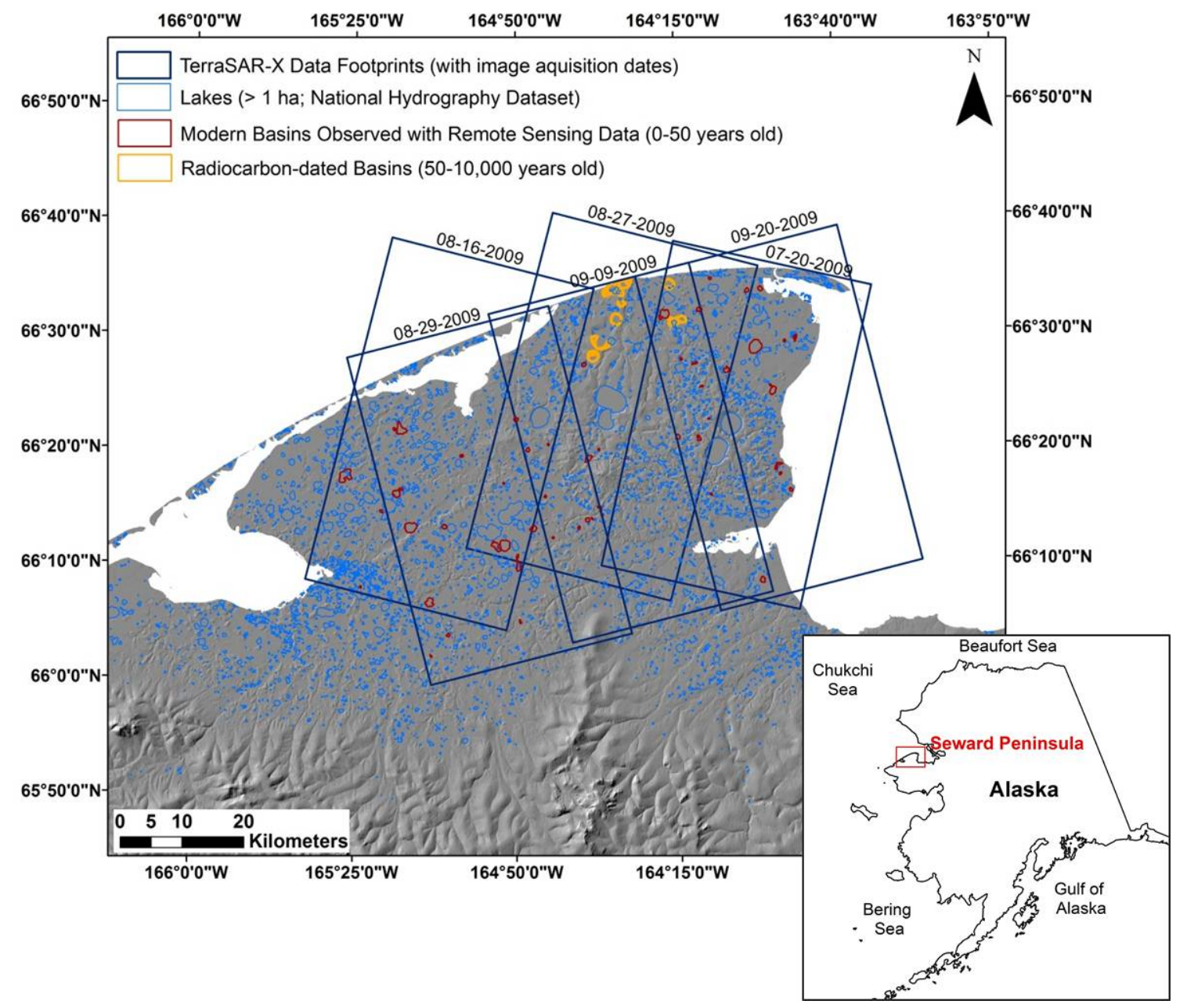

The elevation in the study area ranges from close to sea level near the coast, to less than $50 \mathrm{~m}$ in most of the uplands that consist of erosional remnants of ice-rich deposits. The landscape is dominated by tundra-type vegetation, which is classified as Bering Tundra [44]. Recently drained thermokarst 
lake basins are dominated by productive grasses, such as Calamagrostis canadensis and Dupontia fisherii [10]. The sedge Carex aquatilis is also common in some of the very productive younger basins. Older DTLBs have a higher component of a less productive plant community that includes Carex bigelowii, Eriophorum angustifolium and Sphagnum sp. tundra with Betula nana, Salix sp. and prostrate ericaceous shrubs [10]. Dry surfaces in the older basins, due to heave from reformation of ground ice and the presence of mature ice wedge polygon ridges, may show abundant lichen [10].

Climate in this region is characterized by long cold winters and short growing seasons (May-September) [49]. The mean annual air temperature of the region is $-6.1^{\circ} \mathrm{C}$, and the mean annual precipitation is $255 \mathrm{~mm}$, with roughly $125 \mathrm{~mm}$ falling in the form of snow based on historical summaries for the period 1971-2000 recorded at Kotzebue, Alaska [27], which is located $60 \mathrm{~km}$ to the northeast, but has a similar coastal position as the northern Seward Peninsula [25].

\section{Data}

\subsection{Remotely Sensed Data}

We acquired six TSX stripmap HH polarization images with $3 \mathrm{~m}$ spatial resolution (Table 1). The scenes were acquired during the 2009 growing season between 20 July and 20 September (Figure 1). The image product was received in Multi Look Ground Range Detected (MGD) format with reduced speckle and approximately square resolution cells [50].

To derive NDVI, we utilized a terrain corrected Landsat-5 TM (L1T) scene with $30 \mathrm{~m}$ spatial resolution, the best available optical remote sensing data overlapping with our SAR dataset from the growing season of the year 2009 (Table 1). The dataset was received from the United States Geological Survey (USGS) Earth Resources Observation Systems (EROS) center. The image was acquired on 13 July 2009, around the time of mid-growing season when plant growth has reached sufficient levels and NDVI allows better differentiation of vegetation status [51,52]. We further investigated the surface properties of DTLBs by visually analyzing high resolution oblique aerial photographs of several of the DTLBs and a few available Quickbird and Ikonos images. Aerial photographs were collected in June of 2010 and 2011, whereas the Quickbird and Ikonos images were acquired in the growing season of the year 2006 and 2007.

Table 1. Satellite images used in the study.

\begin{tabular}{cccccc}
\hline Scenes & Acquisition Date & Spatial Resolution & Incidence Angle & Orbit Direction & Polarization \\
\hline TerraSAR-X 1 & $07 / 20 / 2009$ & $3 \mathrm{~m}$ & $35.3^{\circ}$ & Descending & $\mathrm{HH}$ \\
TerraSAR-X 2 & $08 / 16 / 2009$ & $3 \mathrm{~m}$ & $31.0^{\circ}$ & Descending & $\mathrm{HH}$ \\
TerraSAR-X 3 & $08 / 27 / 2009$ & $3 \mathrm{~m}$ & $28.8^{\circ}$ & Descending & $\mathrm{HH}$ \\
TerraSAR-X 4 & $08 / 29 / 2009$ & $3 \mathrm{~m}$ & $31.1^{\circ}$ & Ascending & $\mathrm{HH}$ \\
TerraSAR-X 5 & $09 / 09 / 2009$ & $3 \mathrm{~m}$ & $33.2^{\circ}$ & Ascending & $\mathrm{HH}$ \\
TerraSAR-X 6 & $09 / 20 / 2009$ & $3 \mathrm{~m}$ & $35.3^{\circ}$ & Ascending & $\mathrm{HH}$ \\
Landsat-5 TM & $07 / 13 / 2009$ & $30 \mathrm{~m}$ & - & - & - \\
\hline
\end{tabular}




\subsection{DTLB Data Layer}

We used a set of 74 DTLBs covered in TSX scenes with known age since drainage (Figure 1). For 14 of these DTLBs, age was determined using accelerated mass spectrometry (AMS) radiocarbon-dating of the basal portion of terrestrial peat covering lake sediments, ranging in the age from 225 to 9,410 years BP [10]. For another 60 DTLBs (3-47 years old), the age since their last drainage was determined from multi-sensor aerial and satellite image time series covering the 1950-2010 period using the change detection technique [43]. The ages of these DTLBs were used to compare SAR backscatter and surface spectral properties of each basin for determination of relationships of basin age with backscatter and with NDVI. All radiocarbon-dated basins were completely drained, while basins that drained in the past decades were either partially (approximately less than $10 \%$ water by basin area observed in 2009 images) or completely drained.

\section{Methods}

\subsection{Image Processing}

Absolute radiometric calibration and orthorectification of TSX data was done with GAMMA ${ }^{\mathrm{TM}}$ software. The best available digital elevation model (DEM) for our study region, the National Elevation Dataset (NED) with $60 \mathrm{~m}$ spatial resolution, was used to perform orthorectification. The performance of this correction was assessed visually by overlaying geocoded TSX images on the terrain-corrected Landsat-5 TM image. Speckle removal in the TSX images was performed using IDRISI $^{\mathrm{TM}}$ image processing software by applying a $5 \mathrm{X} 5$ window mean filter. Since GAMMA provided the radar backscatter $\left(\sigma^{\circ}\right)$ values in linear unit (intensity values), they were converted to decibels (dB) after we performed filtering and extracted the mean backscatter value of drained basins for further analysis. A NDVI dataset was produced using Landsat-5 TM band-3 (red) and band-4 (near infrared) using Equation (1) [53].

$$
\text { NDVI }=\frac{\text { Near Infrared }- \text { Red }}{\text { Near Infrared }+ \text { Red }}
$$

Since the objective of the study was to investigate the relationship between backscatter and NDVI with basin age, remnant water bodies in all DTLBs were masked from all TSX scenes, as well as the Landsat NDVI image using IDRISI software. To mask water bodies, a threshold method separating land from water surfaces was applied to the TSX images, and the same method was applied to band-5 (first shortwave infrared band) of the Landsat image. A threshold of $-14 \mathrm{~dB}$ was chosen to mask out water bodies from TSX images, and a threshold of $31 \mathrm{DN}$ (digital numbers) was chosen for Landsat band 5.

\subsection{TSX Backscatter and NDVI of DTLBs}

Both backscatter and NDVI of DTLBs were examined using the desktop geographical information system (GIS) software ArcMap 10. Using the Zonal Statistics tool, the mean backscatter value $\left(\sigma^{\circ}\right.$ intensity) of 60 DTLBs (younger than 50 years) was extracted from all six TSX scenes, and the mean backscatter ( $\sigma^{\circ}$ intensity) of 14 radiocarbon-dated DTLBs (older than 50 years) was extracted from 27 August and 09 September 2009 TSX scenes. We selected these two scenes because their spatial coverage includes all 14 radiocarbon-dated DTLBs completely. The final mean $\sigma^{\circ}$ was converted from 
intensity to dB. We could extract NDVI of only 57 modern DTLBs that were visible in the cloud- and cloud shadow-free portions of the Landsat image from 13 July 2009. We were able to extract NDVI for all 14 radiocarbon-dated DTLBs. Mean basin backscatter $(\mathrm{dB})$ and mean basin NDVI were used to investigate the backscatter and spectral properties of DTLBs with different ages. We used age classes based on calendar years in correspondence with those used by Jones et al. [10] (Table 2): 0-50 years (modern), 50-500 years (young), 500-2,000 years (medium), 2,000-5,000 years (old) and older than 5,000 years (ancient).

To investigate the relationship between backscatter and NDVI of DTLBs, we performed a regression analysis between mean basin backscatter and mean basin NDVI with basin age in three subsets of our DTLB dataset: (1) 0-50 years since drainage, or modern DTLBs; (2) 50-10,000 years since drainage, or radiocarbon-dated DTLBs; and (3) 0-10,000 years since drainage, or combined modern and radiocarbon-dated DTLBs.

The analysis of mean backscatter versus basin age was performed for each TSX image separately on all 60 modern DTLBs that were covered by respective scenes acquired on different dates (Figure 1) to avoid biases in our basin age analysis that could be produced from seasonal dynamics of basin parameters. Similarly, for 14 radiocarbon dated DTLBs, we used mean basin backscatter extracted from 27 August 2009 and 09 September 2009 TSX scenes (Figure 1) to investigate if backscatter signals reflect their successional stage. Mean NDVI of 57 modern and 14 radiocarbon-dated DTLBs were used to investigate the relationship between NDVI of modern and radiocarbon-dated DTLBs and their age.

To explore the relationship between backscatter properties with age of basins ranging from 0 to 10,000 years, we analyzed backscatter signals of DTLBs that were covered in 27 August 2009 and 09 September 2009 TSX scenes separately. Also, we explored the relationship between NDVI signals on 13 July of these basins with their age. We excluded three modern DTLBs from our analysis of basin backscatter and NDVI due to clouds or cloud shadows or being located outside of the Landsat extent from our analysis to make the basin backscatter property comparable with its NDVI property. In total, there were 39 DTLBs, among which 25 were modern and 14 were radiocarbon-dated.

\section{Results}

\subsection{TSX backscatter and NDVI Properties of Modern DTLBs (0-50 Years since Drainage)}

Analysis of TSX backscatter of modern DTLBs did not result in a clear relationship between basin age and mean basin backscatter. We did not find strong relationships for 16 and 29 August $\left(\mathrm{R}^{2}<0.25\right.$, $\mathrm{p}<0.05$ ), and no statistically significant relations were established for other dates. Also a strong relationship could not be established between NDVI on 13 July and basin age for modern basins $\left(\mathrm{R}^{2}<0.25, \mathrm{p}<0.05\right)$.

During aerial field surveys, we observed strong local variation in early post-drainage surface backscatter and NDVI properties within most modern basins based on varying vegetation communities and variable soil moisture conditions (Figure 2(a,b)). Additionally, backscatter and NDVI properties varied between modern basins of the same age. Most of the vegetated DTLBs that drained in the last five years consisted of early assemblages of highly productive, high canopy $(50-130 \mathrm{~cm}$ tall) graminoid vegetation, often densely growing in very shallow water $(<30 \mathrm{~cm}$ deep) (Figure $2(\mathrm{a}))$. These 
DTLBs exhibited the highest NDVI, but had a very low backscatter signal. Some of the DTLBs were still in the process of draining (Figure 2(b)). Many of the partially drained basins contained lush vegetation growing in remnant ponds, some of which was partly emergent from the water, but did not cover the water surface uniformly, while other areas formed floating vegetation mats growing around the edges of water surfaces [54]. Such DTLBs dominated by emergent vegetation and floating vegetation showed a very high X-band backscatter. However, their NDVI was highly variable depending on vegetation type and density versus open water areas in between patches of vegetation. Further, some DTLBs had areas drained more and primarily covered with moss and lichen. This type of surface exhibited relatively low NDVI and intermediate to low backscatter.

Figure 2. Oblique aerial photographs of DTLBs located on the northern Seward Peninsula at various stages after drainage showing evolution of basin floor characteristics. Photos were collected during field visits in late June 2010 and 2011. (a) Early assemblage of highly productive grass vegetation emerging from very shallow water in recently drained modern basin. As the growing season progresses, the graminoid vegetation grows to $50-130 \mathrm{~cm}$ tall, densely covering the basin floor. (b) A typical characteristic of modern shallow basins after a few decades after drainage is that some parts of the basin get drier and some remain inundated, depending on local topography and hydrological characteristics. A mixed vegetation community is observed in such basin types. (c) Dry basin floor with willows growing in a young basin. (d) Polygonization and ponding in a medium age basin.

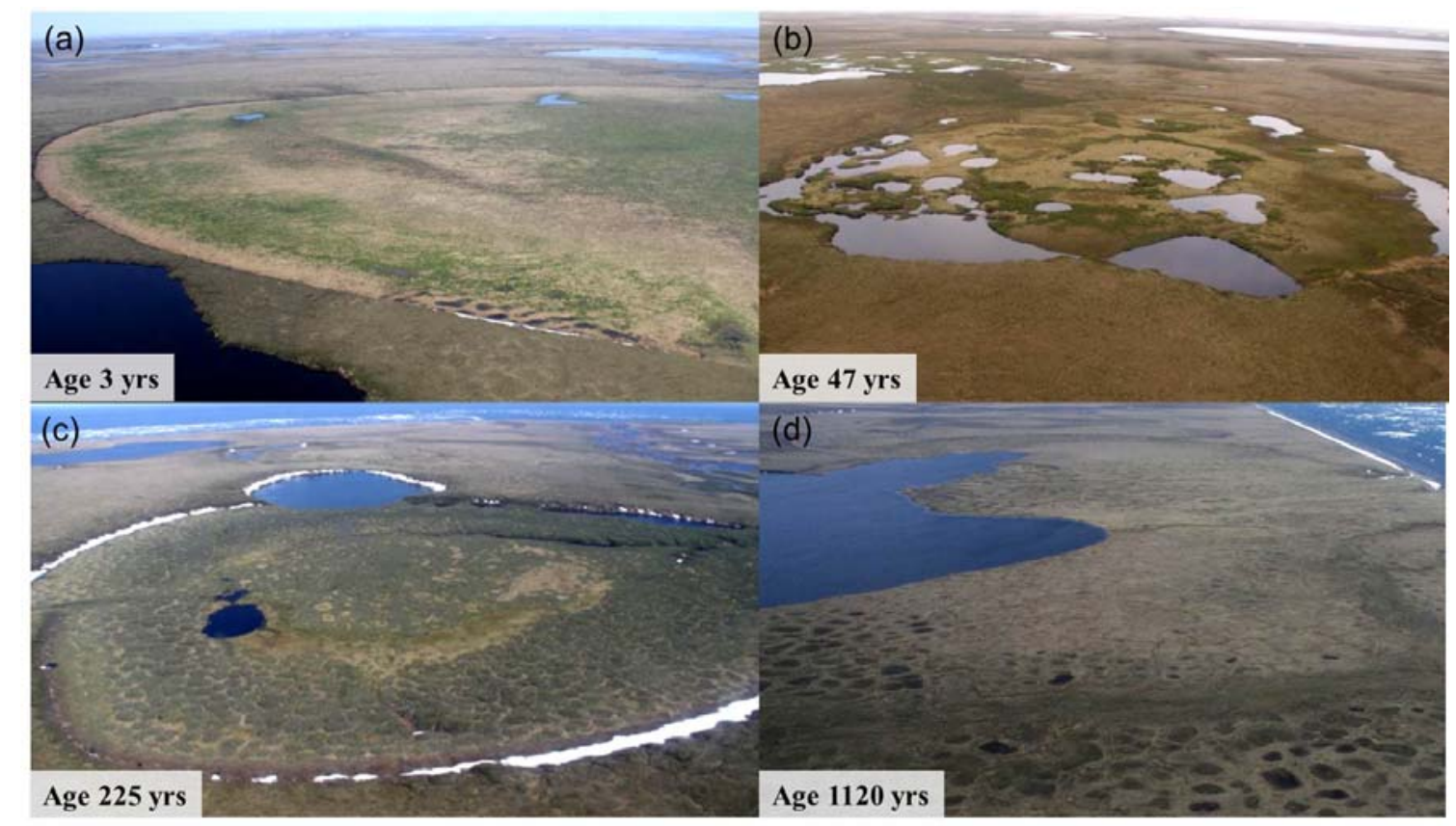

\subsection{TSX Backscatter and NDVI Properties of Radiocarbon-Dated DTLBs (50-10,000 Years} since Drainage)

Analysis of TSX backscatter on 27 August of the radiocarbon-dated DTLBs indicated a significant logarithmic relationship $\left(\mathrm{R}^{2}=0.58 ; \mathrm{p}<0.05\right)$ between basin age and mean basin backscatter (Figure 3). Younger radiocarbon-dated DTLBs showed higher backscatter, while backscatter decreased 
for older and ancient basins. However, there was no significant relationship between 09 September backscatter and basin age. Similarly, NDVI from 13 July did not show a significant relation between NDVI of DTLBs and their radiocarbon-dated age.

Figure 3. Plot of mean basin backscatter observed on 27 August 2009 against basin age showing a logarithmic relationship for the period of 0-10,000 years and 50-10,000 years. Basin age class is shown as: I. Modern basins; II. Young basins; III. Medium age basins; IV. Old basins; and V. Ancient basins.

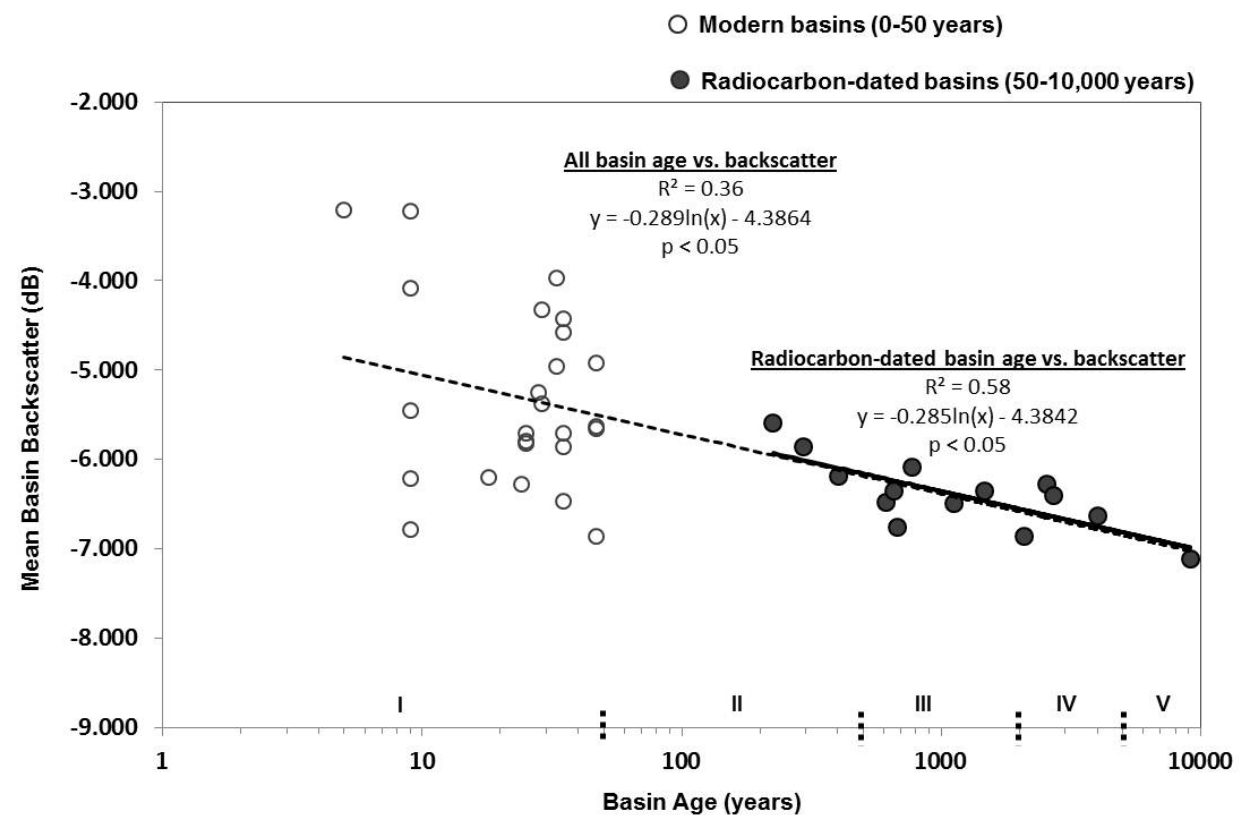

Young DTLBs had relatively high backscatter values that ranged between $-6.1 \mathrm{~dB}$ and $-5.5 \mathrm{~dB}$. They had variable but relatively high NDVI values. They largely had not yet developed polygonal networks and had more productive vegetation than older basins (Figure 2(c)), except one that drained 294 years BP situated in the northern coastal lowland. This particular basin was less productive, also indicated by its very low NDVI value, and had developed early stage low-centered polygons. The basins were already characterized by drier surfaces and were affected by frost heave. We observed that DTLBs of medium age (younger than $\sim 1,000$ years BP) were generally drier and exhibited early low-center ice-wedge polygonal networks (Figure 2(d)). Consequently, backscatter values decreased within the range of $-6.7 \mathrm{~dB}$ and $-6 \mathrm{~dB}$ for these basins. They generally had similar vegetation cover and NDVI to that of young DTLBs, but with much less variability, indicating homogenization of vegetation cover in the basins with ongoing succession. Only one medium-aged basin dated to 615 years BP in the northern coastal lowland had already developed characteristics of older medium aged DTLBs (older than $\sim 1,000$ years). Older medium aged DTLBs exhibited lower backscatter. They had fully established low-centered polygonal networks with some wet centers and ponded polygons. Moreover, less productive lowland tundra vegetation had dominated these basin floors.

Mean basin backscatter values continued to decrease for old and ancient DTLBs ranging between $-7.1 \mathrm{~dB}$ and $-6.2 \mathrm{~dB}$. Old and ancient DTLBs were characterized by fully established ice-wedge polygonal networks either with dry soil surfaces or with a significant number of ponded low-centered polygons in some cases, indicating the potential for coalescence into a new lake. DTLBs with a large 
topographic gradient within and downstream of their drainage channels often did not appear to pool sufficient surface runoff for forming new ponds and development into a new lake, while basins with a low topographic gradient had often more ponds. We observed emergent vegetation in some of the inundated centers of the polygons. Such parts of DTLBs exhibited high backscatter. Some old DTLBs also contained fully developed large hydrostatic pingos. These pingos exhibited high NDVI compared to the basin floor surrounding it, but their backscatter signal was affected by geometric distortion on the steep pingo slopes. Geometric distortion, an inherent problem in SAR acquisition mainly of rugged terrain, is a spatial distortion due to complex relationship between SAR look direction, incident angle, target object platform altitude and object configuration relative to radar beam. It causes terrain slope of elevated targets, such as large pingos, facing towards the SAR sensor to appear compressed and brighter [55]. Even though some parts of older DTLBs contained features that exhibited higher NDVI and backscatter signals, such features were considerably less in number and, thus, had a small contribution to total mean backscatter and NDVI values of DTLBs, which was therefore relatively lower than younger DTLBs.

\subsection{TSX Backscatter and NDVI Properties of Modern and Radiocarbon-Dated DTLBs (0-10,000 Years since Drainage)}

Analysis of TSX backscatter in the 27 August scene of the entire suite of DTLBs of known age (modern and radiocarbon-dated DTLBs) resulted in a significant logarithmic relation $\left(\mathrm{R}^{2}=0.36\right.$, $\mathrm{p}<0.05$ ) between basin age and mean basin backscatter (Figure 3). However, a strong relationship could not be established $\left(\mathrm{R}^{2}<0.2, \mathrm{p}<0.05\right)$ between backscatter and basin age for the 09 September TerraSAR-X scene. A significant and even stronger logarithmic relation of $R^{2}=0.53(p<0.05)$ was found between basin age and Landat-5 TM based NDVI (Figure 4). There was a decreasing trend in basin scale backscatter as basin age increased. A similar trend was observed in NDVI, but this relationship did not hold for the ancient basin (older than 5,000 years). NDVI value increased for the only ancient basin in our dataset.

The most notable successional transition was found between modern and young DTLBs. Modern DTLBs exhibited a generally higher variability in their spectral and backscatter properties compared to older DTLBs (Figures 5 and 6), indicative of their highly variable surface properties, while young basins were already characterized by tundra vegetation and drier and refrozen soils. Modern basins had a wide range of backscatter values between $-6.8 \mathrm{~dB}$ to $-3.2 \mathrm{~dB}$. Several of them had low backscatter values similar to those of young and medium-aged DTLBs, even though they were characterized by different surface properties. We found that the basin productivity decreased significantly within 50-500 years after lake drainage. Modern DTLBs exhibited relatively high NDVI in the range of 0.32 to 0.52 , compared to NDVI for radiocarbon-dated DTLBs that ranged from 0.27 to 0.47 . We noticed that the rate of basin floor modification was much slower when basins reached medium age, as also reflected from their backscatter and NDVI values that did not vary much after this point. The characteristics of drained basins are illustrated in Figure 7 and summarized in Table 2. 
Figure 4. Plot of mean basin NDVI observed on 13 July 2009 against basin age showing a logarithmic relationship for the period of $0-10,000$ years. Basin age class is shown as: I. Modern basins; II. Young basins; III. Medium age basins; IV. Old basins; and V. Ancient basins.

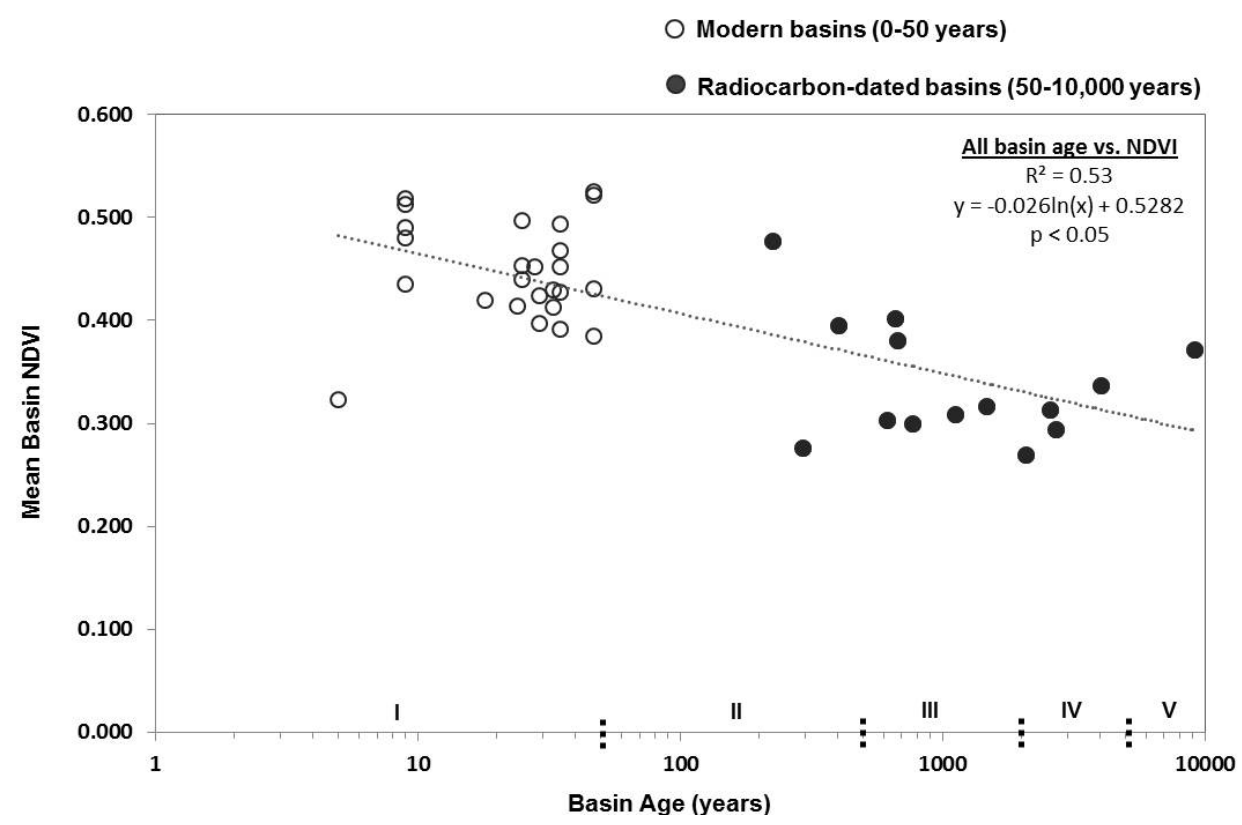

Figure 5. Backscatter and NDVI properties of DTLBs at various stages in a subset of the study area on the northern Seward Peninsula as observed in: (a) TerraSAR-X image (3 m spatial resolution) on 27 August 2009; and (b) Landsat-5 TM based NDVI (30 m spatial resolution) on 13 July 2009.

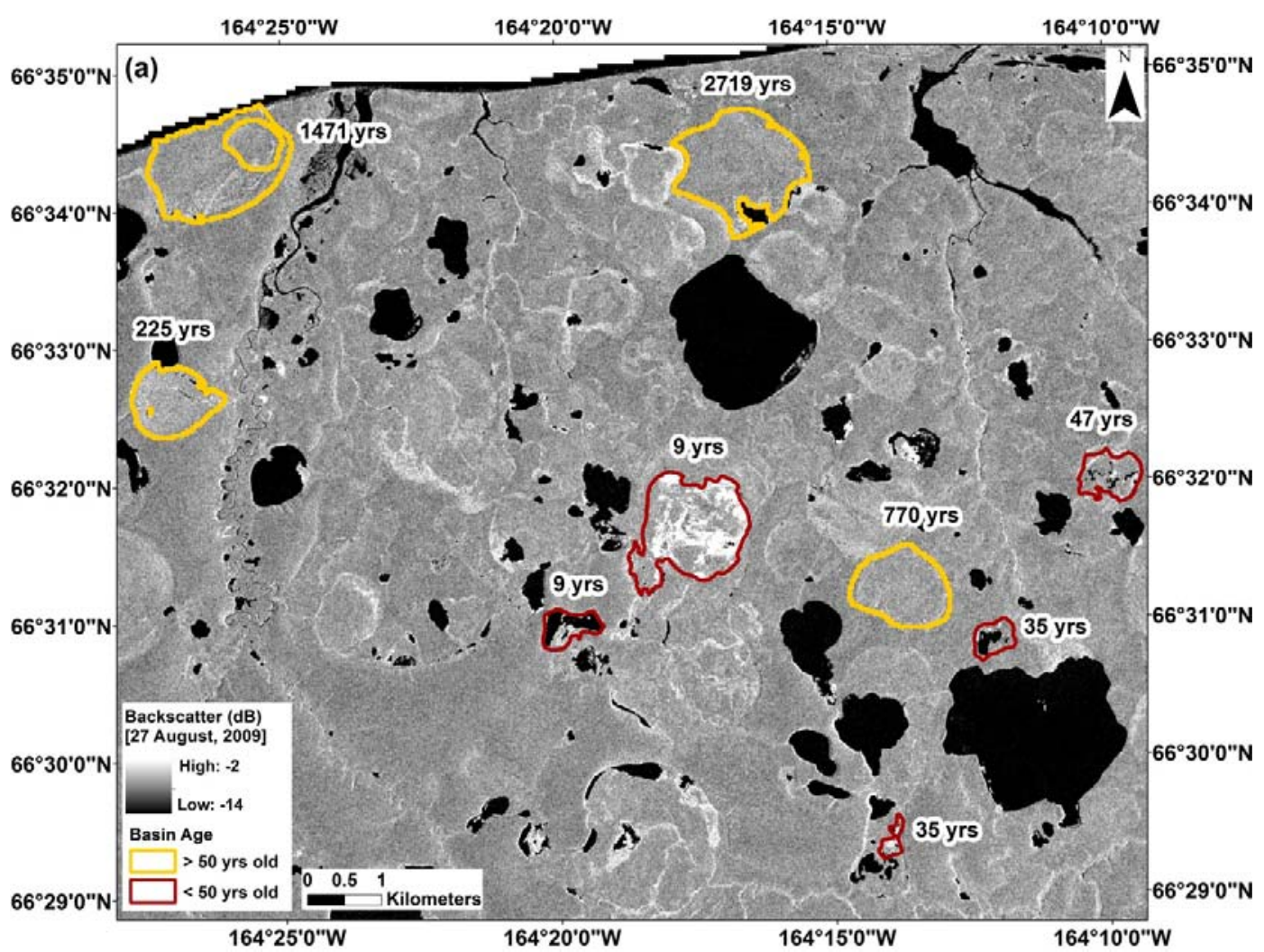


Figure 5. Cont.

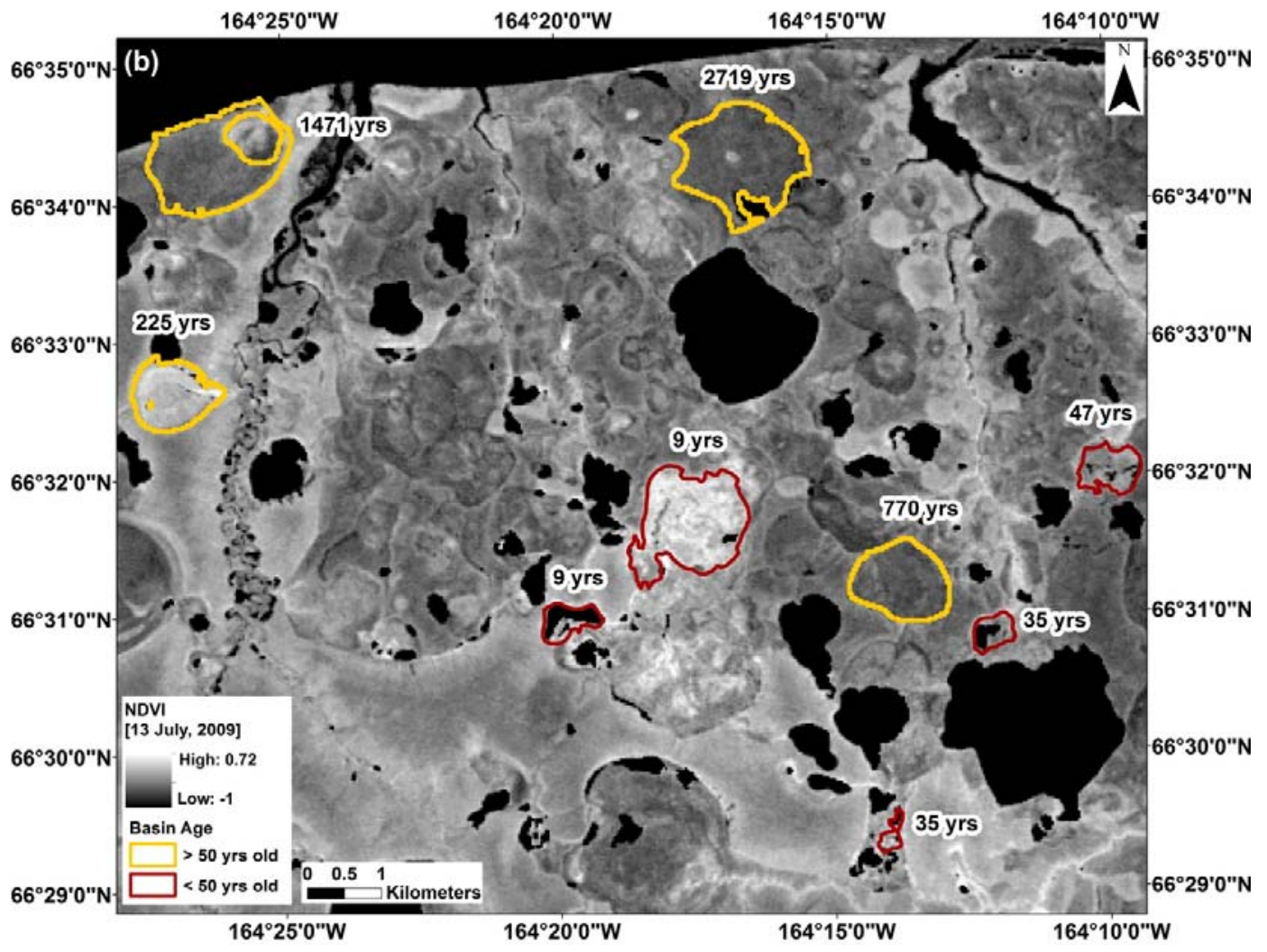

Figure 6. Distribution of backscatter and NDVI values of DTLBs showing the differences in backscatter and spectral properties of modern and radiocarbon-dated basins. The axes intersect at the median of each parameter.

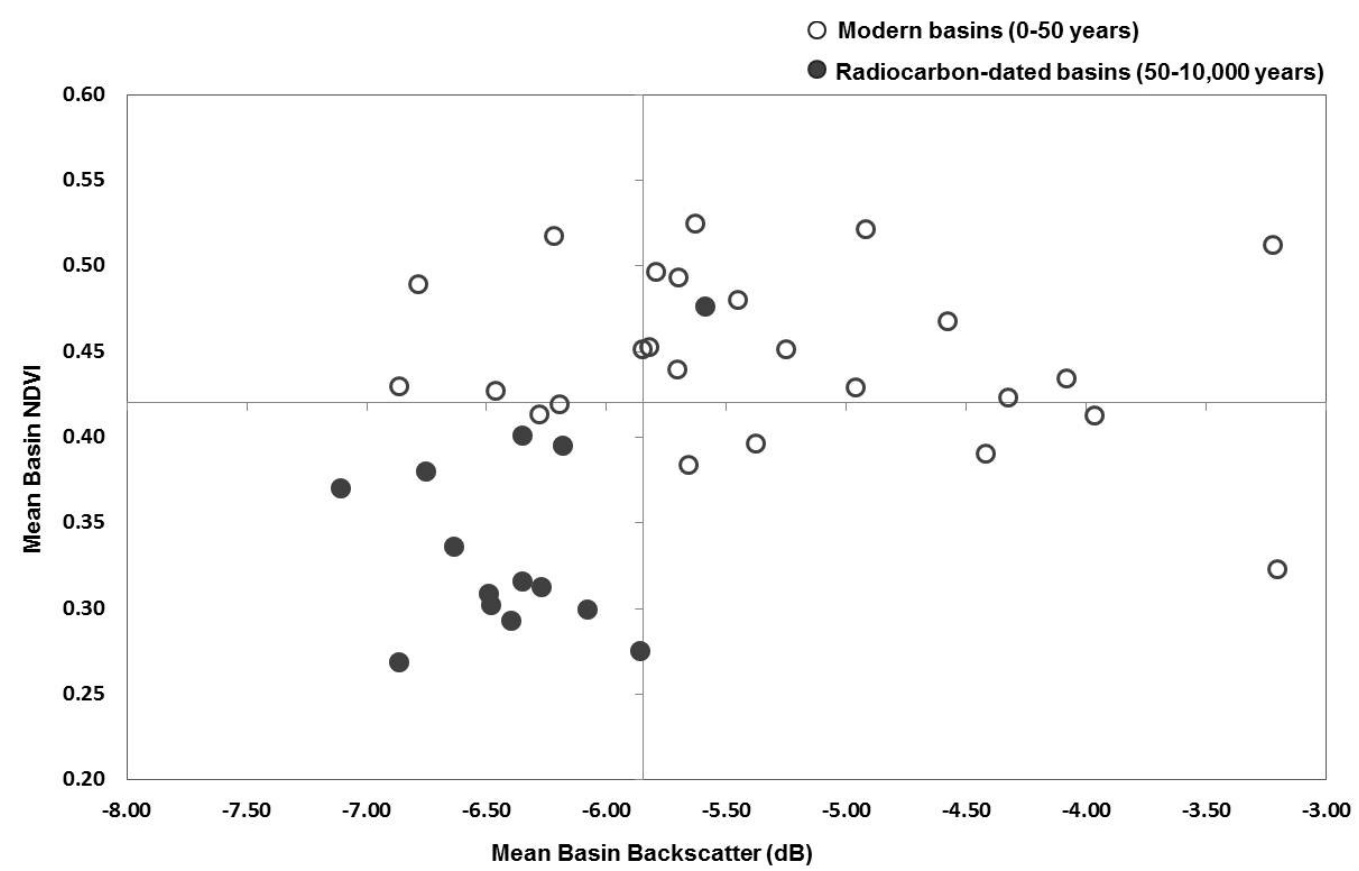


Table 2. Characteristics of basins of different age on the northern Seward Peninsula.

\begin{tabular}{|c|c|c|c|c|c|}
\hline Basin Class* & Modern (0-50 years) & Young (50-500 years) & Medium (500-2,000 years) & Old $(2,000-5,000$ years $)$ & Ancient $(>5,000$ years $)$ \\
\hline Number of basins studied & 60 & 3 & 6 & 4 & 1 \\
\hline $\begin{array}{l}\text { Mean late summer ( } 27 \text { August) } \\
\text { TSX backscatter (dB) }\end{array}$ & $-5.3 \pm 0.99$ & $-5.88 \pm 0.24$ & $-6.42 \pm 0.20$ & $-6.54 \pm 0.23$ & -7.11 \\
\hline $\begin{array}{l}\text { Mean mid-summer (13 July) } \\
\text { NDVI }\end{array}$ & $0.45 \pm 0.05$ & $0.38 \pm 0.08$ & $0.33 \pm 0.04$ & $0.30 \pm 0.02$ & 0.37 \\
\hline Vegetation & $\begin{array}{l}\text { High average gross primary pro } \\
\text { with dominating plant species* } \\
\text { Calamagrostis canadensis, } \\
\text { Dupontia fisherii, } \\
\text { Carex aquatilis. }\end{array}$ & ctivity & $\begin{array}{l}\text { Low avera } \\
\text { with domi1 } \\
\text { Carex bige } \\
\text { Betula nan } \\
\text { polygonal } \\
\text { aquatilis. }\end{array}$ & $\begin{array}{l}\text { oss primary productivity } \\
\text { g plant species* } \\
\text { i, Eriophorum angustifoliun } \\
\text { lix sp., and prostrate ericac } \\
\text { ls in older basins contain pr }\end{array}$ & $\begin{array}{l}\text { Sphagnum fuscum, } \\
\text { hrubs. However, low-centered } \\
\text { ve species such as Carex }\end{array}$ \\
\hline
\end{tabular}

Frost heave occurs due to

refreezing of lake sediments and

Lake sediment starts to refreeze after drainage over several years to decades as a result of exposed lake bottom.

High soil moisture and standing water in most lowland basins,

Basin wetness low soil moisture in upland basins where steeper topographic gradient allows better drainage.

\section{taliks and ground ice}

accumulation. Frost cracking occurs; in basins that only had very shallow lakes, not thawedout ice wedge networks, may become reactivated.

Beginning development of polygonal networks creates micro-mosaic of wetter and drier areas in basins, polygonal ponds develop.
Low-center ice-wedge polygonal networks are largely well developed.

\section{Polygonal ponds} appear widely in low center polygons. Ponded polygons are more distinct in older medium aged basins ( $>1,000$ years)
Basins have very well developed low-center ice-wedge polygonal networks. Some basins have fully developed hydrostatic pingos. In some basins, ground ice is sufficient to allow development of new thermokarst ponds and expansion of small remnant lakes.

Peat carbon stocks* $\left(\mathrm{kg} \cdot \mathrm{C} \cdot \mathrm{m}^{-2}\right)$

$11.8 \pm 2.4$
$17.3 \pm 7.8$
Long-term frost heave, including pingo formation, results in drying of central basin areas. Some basins have increased number of polygonal and ice wedge through ponds, whereas basins with a steep topographic gradient become drier. 
Figure 7. DTLB of different age classes located in the northern Seward Peninsula (Modern: (a) 9 yrs old, (b) 29 yrs old; Young: (c) $403 \pm 55 \mathrm{cal} \cdot \mathrm{yr} \cdot \mathrm{BP}$, (d) $294 \pm 15$ cal·yr·BP; Medium: (e) $1471 \pm 60 \mathrm{cal} \cdot \mathrm{yr} \cdot \mathrm{BP}$, (f) $770 \pm 35 \mathrm{cal} \cdot \mathrm{yr} \cdot \mathrm{BP}$; Old: (g) $2719 \pm 40$ cal·yr·BP, (h) $2567 \pm 80 \mathrm{cal} \cdot \mathrm{yr} \cdot \mathrm{BP}$; Modern basin ages from Grosse et al. [43] and radiocarbon dates from Jones et al. [10]). All images show bands 4-3-2 (near-infrared, red, green) and are in same scale. Image $C$ is from Quickbird (C) DigitalGlobe; all others are from IKONOS (C) GeoEye. Vegetation appears in shades of pink with darker color representing high biomass. Water appears dark bluish or black, and bare or sparsely vegetated soil appears in shades of light blue or grey.
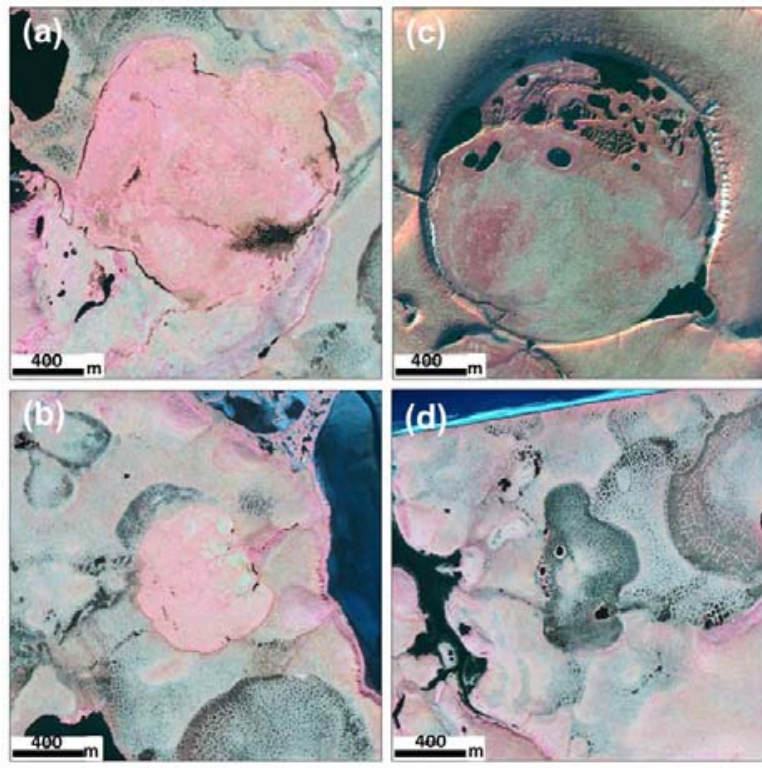
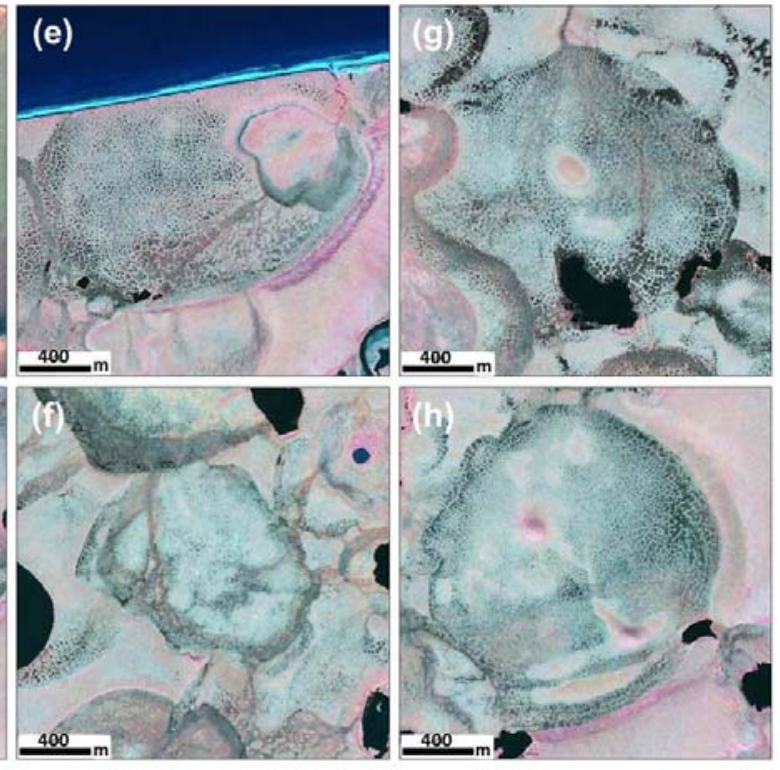

\section{Discussion}

\subsection{Uncertainties}

Several components in this study are associated with uncertainties, though a detailed quantification of these uncertainties remains difficult due to a lack of appropriate data for comparison at this point. First, the remote sensing data represents, like in any other remote sensing study, a snapshot in time that reflects specific environmental conditions on the ground. Comparison with climate data from the Kotzebue climate station for the times of image acquisition indicated that the images were not taken in or directly after periods of unusual weather events and the image data seems generally representative for the observation periods. Second, NDVI and backscatter may be scale-dependent, and a comparison between these parameters should ideally be done at the same pixel resolution. In our case, no suitable high-resolution data was available for the time of the TSX acquisitions, and we therefore chose Landsat data for NDVI closest to the TSX acquisition date. Though the Landsat data is from earlier in the growing season than our TSX images, the present general patterns of NDVI still provide a valuable insight into basin-wide vegetation distribution and phenology that are useful for interpreting TSX backscatter results.

Eventually, some uncertainty in this study arises from the relatively low number of samples for radiocarbon dated basins. In our study, several basins were dated by radiocarbon dating of basal 
terrestrial peat in a single core from a central portion of the basin [10]. These locations were considered to be representative for the entire basin based on aerial image and field analyses. Arguably, there may be heterogeneity in drained lake basins based on geological and hydrological history that also could affect the timing of peat accumulation. Only cost-intensive, additional radiocarbon dating could provide detailed insights in these particular uncertainties. However, radiocarbon basal peat dates of overlapping neighboring basins indicate that the method is suitable, as the ages of these basins were generally in agreement with their geomorphological position towards each other. Jones et al. [10] and Hinkel et al. [12] address some of the issues related to basin sampling and basin age determination in more detail. Due to a relatively small available sample size of basins with known age, we also were not able to explore general differences between upland and lowland basins. While lowland basins have low topography and a lower drainage gradient, upland basins usually have a steeper drainage gradient, likely resulting in different succession patterns of post-drainage soil moisture, vegetation and permafrost development. We suggest that some of the heterogeneity in our dataset results from mixing these two types of basins.

\subsection{Surface Characteristics of Modern DTLBs (0-50 Years since Drainage)}

Based on our results, a 50-year time period after lake drainage appears too short to observe a predictable succession of vegetation and changes in soil properties using a space-for-time substitution approach with TSX backscatter and Landsat-based NDVI data of DTLBs with varying ages. However, this may not exclude the presence of clear relationships due to successional changes within individual basins that could be observed with a time series of imagery. Local variations of the draining process related to drainage gradient, basin size and watershed size likely played a significant role in determining successional stage and hydrologic regimes of modern basins. For enhanced differentiation, the application of a high resolution Digital Elevation Model (DEM) would be useful to stratify basins based on their hydro-geomorphic regime [11] and allow an enhanced evaluation of the relationship between basin age and backscatter or spectral data on different basin subsets. However, due to a lack of fine resolution DEM for our study region, we could not follow this approach. Similarly, due to variation in surface drainage within a basin floor, the basin floor was characterized by diverse soil moisture and vegetation composition. This resulted in mixed and spatially complex backscatter and spectral pixel-signal that largely prevented a solid discrimination of successional stages of modern DTLBs after lake drainage. Eisner and Peterson [19] and Hinkel et al. [12] have also observed this variability within one basin as an inherent source of error in age classification of basins on the Barrow Peninsula, North Alaska.

The high backscatter of sparsely distributed emergent vegetation and floating vegetation mats in our study is likely due to deeper penetration of the shorter wavelength X-band radiation through a vegetation canopy, which then results in the double bounce reflection from the water and vegetation [56]. In our study, incidence angles of all the TSX scenes were very close to each other, ranging from $28.8^{\circ}$ to $35.3^{\circ}$. A smaller incidence angle shortens the path through canopy and reduces the canopy attenuation on the radar signal, allowing it to penetrate deeper [57]. Töyrä et al. [58] showed similar results for radar backscattering from flooded willow, grasses and sedges in the Peace-Athabasca Delta, Canada. 
For very young DTLBs (younger than five years old) with shallow water and an early assemblage of densely populated and productive graminoid vegetation, the low backscatter value can be explained by a decreasing contribution of a signal from the wet soil surface and the increasing biomass [59]. In this case, even at a low incidence angle, the shorter wavelength of X-band cannot penetrate through the denser canopy layer and detect the background. The interaction of canopy and radiation takes place within the volume of the vegetation canopy that is composed of multiple scatterers with different sizes and orientation [56]. This results in volume and multiple scattering with low return signal. Similar radiation-canopy interaction is observed in parts of other modern DTLBs, which have dense graminoid cover.

For some dry basin surfaces with moss and lichen cover or exposed ground, likely a result of higher elevated surfaces of the former lake bottom exposed very early in the drainage process, it is possible that X-band could have penetrated the upper thin vegetation layer covering the basin floor [40,60]. Therefore, the moisture of the underlying soil could have contributed more to the total backscatter from dry basin surfaces. Aubert et al. [61] in their analysis of TSX data sensitivity to bare soil moisture and roughness have shown that the sensitivity of the radar signal to soil moisture for TSX is higher at smaller incidence angles similar to the ones we have used in our study. In contrast, it is less sensitive to soil roughness. Past studies have documented that soil with low moisture content exhibits lower backscatter and that backscatter increases linearly with increasing moisture for soil with volumetric soil moisture contents between $0 \%$ and approximately $35-40 \%$, after which the backscatter coefficient stays constant and then decreases with increasing soil moisture [39,61].

The moderate resolution Landsat data was generally useful to derive mean basin NDVI. Due to a lack of suitable high resolution multispectral optical remote sensing images overlapping with our SAR dataset from the growing season of the year 2009, we could not perform detailed vegetation pattern analysis in basins, particularly in areas influenced by spectral mixing due to partly submerged vegetation in water or small patches of vegetation mats interspersed with patches of open water.

\subsection{Surface Characteristics of Modern and Radiocarbon-Dated DTLBs (0-10,000 Years} since Drainage)

We attribute the logarithmic relationships of basin age with mean basin backscatter and mean basin NDVI in the summer season to post-drainage change in vegetation, soil formation and peat accumulation, and permafrost aggradation. Our analysis also showed seasonal differences in backscatter between the 27 August and 9 September scenes and the lack of a clear relationship in the September scene backscatter with basin age. A plausible explanation could be that seasonal changes in vegetation phenology and soil moisture properties of basin floors obscure the link between backscatter and basin age later in the fall. This suggests that the time of image acquisition should be taken into consideration when investigating post-drainage succession pattern of thermokarst basins using radar datasets. Reidel et al. [52] have already demonstrated variations in NDVI throughout the season and its implications for estimating plant productivity more accurately for the tundra ecosystem. To fully understand the seasonal behavior of basin backscatter and the basin age relationship, further analysis of multi-temporal data is required. 
Diverse surface properties among modern DTLBs, as well as within a modern drained basin, affected the SAR signal in separating modern basins from young and medium-aged basins. This is because of complex and non-linear interaction between radar backscatter and diverse biophysical parameters $[41,57]$ that dominated basin floors during early successional stages after lake drainage. Since modern DTLBs exhibited relatively high NDVI due to mostly dense graminoid vegetation compared to older DTLBs, NDVI was a good indicator of basin age over a period of 0-10,000 years. However, TSX data performed much better when used to discriminate basins older than modern basins (50-10,000 years BP), likely due to the better sensitivity of soil moisture. This shows that the usefulness of NDVI for discrimination of DTLB successional stage diminishes when the rate of vegetation succession slows down in older and less productive basins.

A decreasing trend in basin backscatter with increasing basin age can be explained by the decrease in soil moisture and presence of patterned ground with the increasing number of small ponded low-center polygons in medium-aged, old and ancient DTLBs. It is likely that the reduced specular property resulted in a lower backscatter signal as soil moisture decreased [57] with increased basin age. In the case of some older radiocarbon-dated DTLBs that were dominated by fully developed polygonal networks with a significant number of small ponds, ponded polygons contributed the most to the overall very low backscatter value. Even though a water mask was created to exclude backscatter of larger water bodies from our study, microscale ice wedge polygonal ponds below TSX image resolution had an impact on backscatter properties. However, we found vegetation growing in some inundated areas exhibited high backscatter due to the double bounce effect of the radar signal [56,58]. Despite an overall decrease in productivity of old basins, the waterlogged conditions in low-center ponds in older DTLBs could have created preferential conditions for growth of productive wetland plant communities [32].

The relationship of decreasing NDVI with increasing basin age agrees with findings by Hinkel et al. [12], Zona et al. [32] and Zulueta et al. [36] from their study on DTLBs on the Arctic Coastal Plain of Alaska. Jones et al. [10] also highlighted a significant relation between Landsat-derived NDVI and basin peat thickness on the northern Seward Peninsula, Alaska. They observed a decrease in basin scale NDVI as basin peat depth increased. Decreasing basin productivity, as indicated by decreasing NDVI, is caused by a lack of nutrient availability in older DTLBs as nutrients become sequestered in the peat as the basin ages [32]. It was demonstrated that the highest rate of peat accumulation on the northern Seward Peninsula occurs in young DTLBs [10]. Also, permafrost aggradation and ground ice formation due to thermal insulation by accumulating peat is likely to have an impact on basin vegetation properties, further favoring less productive tundra moss and sedge species over highly productive wetland grass and sedge species. However, the relationship of ancient basin age with NDVI signal is only based on one sample and, therefore, adds an uncertainty in our analysis, whether there are specific biophysical reasons for a repeated increase in NDVI in ancient basins or whether the single data point for ancient basins in our dataset is an outlier. The cause of increased NDVI in ancient basins requires further investigation.

In general, the rate of ice-wedge polygonization we observed for DTLBs in Seward Peninsula is slower than that observed by Hinkel et al. [12] in their study on DTLBs for the Barrow Peninsula, Alaska. They noticed a high rate of polygonization during the first 500 years of basin history. This difference could be related to the relatively warmer climatic conditions of the northern Seward Peninsula compared to the cold climate on the Barrow Peninsula that could restrict regular ice-wedge 
formation in our study area. The depth of the lake occupying the basin before drainage also makes an important contribution to ice volume in drained basins. Portions of ice-wedges may remain under shallow lakes that freeze to the bottom during winter and do not form deep taliks. Therefore, the presence of fully developed ice wedge polygonal networks in some younger radiocarbon-dated basins in our study could be a result of reactivation of old ice wedge networks when exposed to cold temperatures. Further analysis of geomorphic characteristics of these basins can help to better evaluate ice-wedge formation [21].

\subsection{Discussion of Long-Term DTLB Development}

Several authors have described changes in vegetation composition and structure, changes in soil moisture, peat accumulation, permafrost aggradation and development of ponded low-centered polygons in DTLBs [10,12,19,29,32]. The results from our remote sensing study of DTLBs on the northern Seward Peninsula agree with the general findings from the previous studies on DTLBs on the Arctic Coastal Plain of Alaska [12,19,29,32,36]. There is a post-drainage pattern of vegetation succession and change in surface soil properties as DTLBs age. However, our observation is not consistent with the classical concept of a "thaw lake cycle" that assumes that a thermokarst lake goes through a complete cycle from lake to drained basin and back to a lake in a specific time period $[8,34]$. For the northern Seward Peninsula, there is no absolute frequency for a thermokarst lake cycle [10]. In addition to time since drainage, other factors determine the successional stage of a basin and formation of a new lake, including climate variability, basin topography, hydrologic framework, geomorphology and history of lake and basin evolution. A recent study on thermokarst lake dynamics in the northern Seward Peninsula that used multi-temporal satellite and aerial images from 1950 to 2007 demonstrated that small new lakes may reform just decades after drainage of large shallow thermokarst lakes, while remnant lakes from partially drained lake basins often start expanding into neighboring DTLBs or uplands due to shore thermal erosion [27]. The study found that the increase in lake numbers between 1950 and 2007 can be attributed to the partial drainage of larger thermokarst lakes and the formation of multiple smaller remnant ponds and lakes. In our study, the appearance of ponding in some radiocarbon-dated basins and the absence of distinct signs of new lake formation in others suggest that the formation of a new lake in an old drained basin is closely tied to the amount of ice content, local topography, hydrological regime, the rate of vegetation succession and polygonal development [12].

There is a complex relationship between vegetation, topography, hydrology, geomorphic and climatic variables that determines the rate of lake expansion, lake drainage [62,63], as well as permafrost aggradation following lake drainage [33]. This consequently affects the thermokarst lake cycle frequency. Jorgenson and Shur [21] proposed a new conceptual model for the evolution of thermokarst lakes and DTLBs, taking into account the influence of basin topography, soil stratigraphy and ground ice dynamics for the development of the thermokarst lake cycle. However, this model for the North Slope of Alaska does not reflect the strong lateral dynamics we observe on the Seward Peninsula with multiple, mostly partially overlapping lake and basin generations. Future research should be directed towards improving knowledge on factors influencing lake drainage and post-drainage successional patterns of DTLBs and how they interact. 


\section{Conclusion}

We used high-resolution TerraSAR-X (TSX) images in combination with Landsat-5 TM-based Normalized Difference Vegetation Index (NDVI) to explore the application of SAR data for characterizing post-drainage succession in thermokarst lake basins on the Seward Peninsula, Alaska. Backscatter and NDVI properties of 60 known drained thermokarst lake basins (DTLBs) that drained partially or completely since 1950 (modern DTLBs), as well as the properties of 14 DTLBs radiocarbon-dated to be up to 10,000 years BP (young, medium-aged, old and ancient DTLBs) were investigated in three subsets: (1) 0-50 years since drainage, modern basins; (2) 50-10,000 years since drainage, radiocarbon-dated basins; and (3) 0-10,000 years since drainage, modern and radiocarbon-dated basins. Our findings indicate that TSX backscatter and Landsat NDVI can trace long-term (0-10,000 years) succession dynamics of DTLBs related to vegetation, soil and permafrost changes. The logarithmic relationships of basin age with mean basin backscatter and with mean basin NDVI resulted in $\mathrm{R}^{2}=0.36(\mathrm{p}<0.05)$ and $\mathrm{R}^{2}=0.53(\mathrm{p}<0.05)$, respectively. For the $50-10,000$ years period, TSX backscatter data outperformed NDVI in discriminating basin successional stage, likely due to its ability to partially detect soil moisture conditions. We here found $\mathrm{R}^{2}=0.58(\mathrm{p}<0.05)$ between radiocarbon-dated basin age and mean basin backscatter. Overall, there was a decreasing trend in both backscatter and NDVI as basin age increased as a result of post-drainage changes in basin surface properties that include decreasing vegetation productivity after an initial productivity spike, decreasing soil moisture, renewed ice-wedge growth and development of either ponded or dry polygonal networks. However, in modern basins, the 50 year time scale was insufficient to find a clear relationship of basin age with TSX backscatter and NDVI. We noticed that not only time since drainage, but a combination of local environmental factors highly influences the successional stages of a basin. This was more prominent in modern basins. Over time with continuing basin succession and stabilization of basin floor, variability in basin surface properties decreased within a basin, as well as among basins of an age class. Since DTLB dynamics likely affect landscape-scale carbon fluxes in high northern latitudes, it is necessary to better understand the spatial and temporal distribution of thermokarst lakes and DTLBs across large regions. Our study highlights the excellent opportunity to use and combine various remote sensing tools for better estimation of the areal extent of high latitude carbon pools and sources of greenhouse gases associated with thermokarst dynamics. Future research should be directed toward utilizing high-resolution topographic data with SAR data, including short and long wavelengths, as well as optical remote sensing data, to better understand the processes driving the evolution of basins. Additionally, multi-temporal analysis of SAR data for basins would increase our understanding of seasonal soil moisture dynamics and their influence on post-drainage vegetation and soil succession.

\section{Acknowledgements}

We acknowledge support from NASA Carbon Cycle Sciences grant NNX08AJ37G, NSF grant OPP-0732735, and the Western Alaska LCC. We thank the German Space Agency DLR for providing TerraSAR-X images through IPY grant LAN0351. We thank the US National Park Service for permitting our research in Bering Land Bridge National preserve and providing Ikonos imagery. We 
thank four anonymous reviewers and two external USGS reviewers (L. Liu, J. Rover) for helpful comments on the manuscript. Any use of trade, product or firm names is for descriptive purposes only and does not imply endorsement by the US Government.

\section{References}

1. Czudek, T.; Demek, J. Thermokarst in Siberia and its influence on the development of lowland relief. Quaternary Res. 1970, 1, 103-120.

2. Soloviev, P.A. Thermokarst phenomena and landforms due to frost heaving in central Yakutia. Biul. Peryglacjalny 1973, 23, 135-155.

3. Burn, C.R.; Smith, M.W. Development of thermokarst lakes during the Holocene at sites near Mayo, Yukon territory. Permafrost Periglac. Process. 1990, 1, 161-175.

4. Morgenstern, A.; Grosse, G.; Günther, F.; Fedorova, I.; Schirrmeister, L. Spatial analyses of thermokarst lakes and basins in Yedoma landscapes of the Lena Delta. Cryosphere 2011, 5, 849-867.

5. Grosse, G.; Jones, B.; Arp, C. Thermokarst Lakes, Drainage, and Drained Basins. In Treatise in Geomorphology; Elsevier: New York, NY, USA, 2012; in press.

6. Livingstone, D.A.; Bryan, K.; Leahy, R.G. Effects of an arctic environment on the origin and development of fresh-water lakes. Limnol. Oceanogr. 1958, 3, 192-214.

7. Sellmann, P.V.; Brown, J.; Lewellen, R.I.; McKim, H.; Merry, C. The Classification and Geomorphic Implications of Thaw Lakes on the Arctic Coastal Plain, Alaska; US Army CRREL Research Report 344; US Army Cold Regions Research and Engineering Laboratory: Hanover, NH, USA, 1975; p. 21.

8. Hopkins, D.M.; Kidd, J.G. Thaw Lake Sediments and Sedimentary Environments. In Proceedings of the 5th International Permafrost Conference, Trondheim, Norway, 2-5 August 1988; pp. 790-795.

9. Frohn, R.C.; Hinkel, K.M.; Eisner, W.R. Satellite remote sensing classification of thaw lakes and drained thaw lake basins on the North Slope of Alaska. Remote Sens. Environ. 2005, 97, 116-126.

10. Jones, M.C.; Grosse, G.; Jones, B.M.; Walter Anthony, K. Peat accumulation in drained thermokarst lake basins in continuous, ice-rich permafrost, northern Seward Peninsula, Alaska. $J$. Geophys. Res. 2012, 117, 1-16.

11. Wang, J.; Shen, Y.; Hinkel, K.M.; Lyons, E.A. Drained thaw lake basin recovery on the western Arctic Coastal Plain of Alaska using high resolution digital elevation models and remote sensing imagery. Remote Sens. Environ. 2012, 119, 325-336.

12. Hinkel, K.M.; Eisner, W.R.; Bockheim, J.G.; Nelson, F.E.; Peterson, K.M.; Dai, X. Spatial extent, age, and carbon stocks in drained thaw lake basins on Barrow Peninsula, Alaska. Arctic Antarct. Alpine Res. 2003, 35, 391-300.

13. Bockheim, J.G.; Hinkel, K.M.; Eisner, W.R.; Dai, X.Y. Carbon pools and accumulation rates in an age-series of soils in drained thaw-lake basins, Arctic Alaska. Soil Sci. Soc. Am. J. 2004, 68, 697-704.

14. Gorham, E. Northern peatlands: Role in the carbon cycle and probable responses to climatic warming. Ecol. Appl. 1991, 1, 182-195. 
15. Walter, K.M.; Smith, L.C.; Chapin, F.S., III Methane bubbling from northern lakes: Present and future contributions to the global methane budget. Phil. Trans. R. Soc. Lond. B. 2007, 365, $1657-1676$.

16. Zimov, S.A.; Davydov, S.P.; Zimova, G.M.; Davydova, A.I.; Schuur, E.A.G.; Dutta, K.; Chapin III, F.S. Permafrost carbon: Stock and decomposability of a globally significant carbon pool. Geophys. Res. Lett 2006, 33, L20502.

17. Schuur, E.A.G.; Bockheim, J.; Canadell, J.G.; Euskirchen, E.; Field, B.F.; Goryachkin, S.V.; Hagemann, S.; Kuhry, P.; Lafleur, P.M.; Lee, H.; et al. Vulnerability of permafrost carbon to climate change: Implications for the global carbon cycle. BioScience 2008, 58, 701-714.

18. Sitch, S.; McGuire, A.D.; Kimball, J.; Gedney, N.; Gamon, J.; Engstrom, R.; Wolf, A.; Zhuang, Q.; Clein, J.; McDonald, K.C. Assessing the carbon balance of circumpolar Arctic tundra using remote sensing and process modeling. Ecol. Appl. 2007, 17, 213-234.

19. Eisner, W.R.; Peterson, K.M. Pollen, Fungi and Algae as Age Indicators of Drained Lake Basins near Barrow, Alaska. In Proceedings of the 7th International Permafrost Conference, Yellowknife, NWT, Canada, 23-27 June 1998; Lewkowicz, A.G., Allard, M., Eds.; Centre d'études nordiques de l'Université Laval: Quebec, QC, Canada, 1998; pp. 790-795.

20. Yoshikawa, K.; Hinzman, L.D. Shrinking thermokarst ponds and groundwater dynamics in discontinuous permafrost near Council, Alaska. Permafrost Periglac. Process. 2003, 14, 151-160.

21. Jorgenson, M.T.; Shur, Y. Evolution of lakes and basins in northern Alaska and discussion of the thaw lake cycle. J. Geophys. Res. 2007, 112, 1-12.

22. Hopkins, D.M. Thaw lakes and thaw sinks in the Imuruk Lake area, Seward Peninsula, Alaska. $J$. Geol. 1949, 57, 119-131.

23. Carson, C.E.; Hussey, K.M. The oriented lakes of Arctic Alaska. J. Geol. 1962, 70, 417-439.

24. Billings, W.D.; Peterson, K.M. Vegetational change and ice wedge polygons through the thaw-lake cycle in Arctic Alaska. Arctic Alpine Res. 1980, 1, 413-432.

25. West, J.J.; Plug, L.J. Time-dependent morphology of thaw lakes and taliks in deep and shallow ground ice. J. Geophys. Res. 2008, 113, 1-14.

26. Kokelj, S.V.; Lantz, T.C.; Kanigan, J.; Smith, S.L.; Coutts, R. Origin and polycyclic behaviour of tundra thaw slumps, Mackenzie Delta region, Northwest Territories, Canada. Permafrost Periglac. Process. 2009, 20, 173-184.

27. Jones, B.; Grosse, G.; Arp, C.D.; Jones, M.C.; Walter Anthony, K.M.; Romanovsky, V.E. Modern thermokarst lake dynamics in the continuous permafrost zone, northern Seward Peninsula, Alaska. J. Geophys. Res.-Biogeosci. 2011, 116, G00M03.

28. Mackay, J.R. Catastrophic lake drainage, Tuktoyaktuk Peninsula area, District of Mackenzie. Curr. Res.-Bull. Geol. Surv. Can. 1988, 88-1D, 83-90.

29. Bliss, L.C.; Peterson, K.M. Arctic Ecosystems in a Changing Climate. In Plant Succession, Competition, and the Physiological Constraints of Species in the Arctic: An Ecophysiological Perspective; Chapin, F.S., III, Jefferies, R.L., Reynolds, J.F., Shaver, G.R., Svoboda, J., Chu, E.W., Eds.; Academic Press: San Diego, CA, USA, 1992; pp. 111-136.

30. Hinkel, K.M.; Frohn, R.C.; Nelson, F.E.; Einser, W.R.; Beck, R.A. Morphometric and spatial analysis of thaw lakes and drained thaw lake basins in the western Arctic Coastal Plain, Alaska. Permafrost Periglac. Process. 2005, 16, 327-341. 
31. Ling, F.; Zhang, T.J. Modeling study of talik freeze-up and permafrost response under drained thaw lakes on the Alaskan Arctic Coastal Plain. J. Geophys. Res. 2004, 109, D01111.32.

32. Zona, D.; Oechel, W.C.; Peterson, K.M.; Clements, R.J.; Paw, U.K.T.; Ustin, S.L. Characterization of the carbon fluxes of a vegetated drained lake basin chronosequence on the Alaskan Arctic Coastal Plain. Global Change Biol. 2010, 16, 1870-1882.

33. Mackay, J.R.; Burn, C.R. The first 20 years (1978-1979 to 1998-1999) of ice-wedge growth at the Illisarvik experimental drained lake site, western Arctic coast, Canada. Can. J. Earth Sci. 2002, 39, 95-111.

34. Carson, C.E. Radiocarbon dating of lacustrine strands in Arctic Alaska. Arctic 1968, 21, 12-26.

35. Kessler, M.A.; Plug, L.; Walter Anthony, K. Simulating the decadal to millennial scale dynamics of morphology and sequestered carbon mobilization of two thermokarst lakes in northwest Alaska. J. Geophys. Res. 2012, 117, GM00M06.

36. Zulueta, R.C.; Oechel, W.C.; Loescher, H.W.; Lawrence, W.T.; Paw U, K.T. Aircraft-derived regional scale $\mathrm{CO}_{2}$ fluxes from vegetated drained thaw-lake basins and interstitial tundra on the Arctic Coastal Plain of Alaska. Global Change Biol. 2011, 17, 2781-2802.

37. Newton, R.W.; Rouse, J.W., Jr. Microwave radiometer measurements of soil moisture content. IEEE Trans. Antenn. Propag. 1980, 28, 680-686.

38. Shi, J.; Wang, J.; Hsu, A.Y.; O’Neill, P.E.; Engman, E.T. Estimation of bare surface soil moisture and surface roughness using L-band SAR image data. IEEE Trans. Geosci. Remote Sens. 1997, $35,1254-1266$.

39. Baghdadi, N.; Aubert, M.; Cerdan, O.; Franchistéguy, L.; Viel, C.; Martin, E.; Zribi, M.; Desprats, L.F. Operational mapping of soil moisture using Synthetic Aperture Radar data: Application to the Touch Basin (France). Sensors 2007, 7, 2458-2483.

40. Baghdadi, N.; Cresson, R.; Todoroff, P.; Moinet, S. Multitemporal observations of sugarcane by TerraSAR-X images. Sensors 2010, 10, 8899-8919.

41. Bindlish, R.; Barros, A.P. Parameterization of vegetation backscatter in radar-based, soil moisture estimation. Remote Sens. Environ. 2001, 76, 130-137.

42. Stow, D.; Daeschner, S.; Boynton, W.; Hope, A. Arctic tundra functional types by classification of single-date and AVHRR bi-weekly NDVI composite datasets. Int. J. Remote Sens. 2000, 21, 1773-1779.

43. Grosse, G.; et al. Personal Communication. November 2012.

44. Arp, C.D.; Jones, B.M. Geography of Alaska Lake Districts: Identification, Description, and Analysis of Lake- Rich Regions of a Diverse and Dynamic State; US Geological Survey Scientific Investigations Report 2008-5215; USGS National Center: Reston, VA, USA, 2009; p. 40.

45. Charron, S.D. Surficial Mapping of the Cape Espenberg-Devil Mountain Region and Lake Core Analyses from North Killeak Lake, Bering Land Bridge National Preserve, Western Alaska. Master Thesis, University of Massachusetts, Amherst, MA, USA, 1995.

46. Smith, S.L.; Romanovsky, V.E.; Lewkowicz, A.G.; Burn, C.R.; Allard, M.; Clow, G.D.; Yoshikawa, K.; Throop, J. Thermal state of permafrost in North America: A contribution to the International Polar Year. Permafrost Periglac. Process. 2010, 21, 117-135. 
47. Hopkins, D.M.; Karlstrom, T.N.V.; Black, R.; Pewe, T.L.; Fernold, A.T.; Muller, E.H. Permafrost and Ground Water in Alaska; US Geological Survey Professional Paper 264-F; USGS: Washington, DC, USA, 1955; p. 70.

48. Burn, C.R.; Kokelj, S.V. The environment and permafrost of the Mackenzie Delta area. Permafrost Periglac. Process. 2009, 20, 83-105.

49. Rupp, T.S.; Chapin, F.S., III; Starfield, A.M. Response of subarctic vegetation to transient climatic change on the Seward Peninsula in north-west Alaska. Global Change Biol. 2000, 6, 541-555.

50. Roth, A.; Hoffmann, J.; Esch, T. TerraSAR-X: How can High Resolution SAR Data Support the Observation of Urban Areas? In Proceedings of the ISPRS WG VII/1 "Human Settlements and Impact Analysis", 3rd International Symposium Remote Sensing and Data Fusion Over Urban Areas (URBAN 2005) and 5th International Symposium Remote Sensing of Urban Areas (URS 2005), Tempe, AZ, USA, 14-16 March 2005.

51. Stow, D.A.; Hope, A.; McGuire, D.; Verbyla, D.; Gamon, J.; Huemmrich, F.; Houston, S.; Racine, C.; Sturm, M.; Tape, K.; et al. Remote sensing of vegetation and land-cover change in Arctic tundra ecosystems. Remote Sens. Environ. 2004, 89, 281-308.

52. Riedel, S.M.; Epstein, H.E.; Walker, D.A. Biotic controls over spectral reflectance of arctic tundra vegetation. Int. J. Remote Sens. 2005, 26, 2391-2405.

53. Tucker, C.J. Red and photographic infrared linear combinations for monitoring vegetation. Remote Sens. Environ. 1979, 8, 127-150.

54. Parsekian, A.D.; Jones, B.M.; Jones, M.C.; Grosse, G.; Walter Anthony, K.M.; Slater, L. Geometry of floating vegetation mats on the expanding margins of thermokarst lakes, Northern Seward Peninsula, Alaska, USA. Earth Surf. Process. Landf. 2011, 36, 1889-1897.

55. Li, S. Summer environmental mapping potential of a large-scale ERS-1 SAR mosaic of the state of Alaska. Int. J. Remote Sens. 1999, 20, 387-401.

56. Costa, M.P.F.; Niemann, O.; Novo, E.; Ahern, F. Biophysical properties and mapping of aquatic vegetation during the hydrological cycle of the Amazon floodplain using JERS-1 and Radarsat. Int. J. Remote Sens. 2002, 23, 1401-1426.

57. Wang, Y.; Hess, L.L.; Filoso, S.; Melack, J.M. Understanding the radar backscattering from flooded and non-flooded Amazonian Forests: Results from canopy backscatter modeling. Remote Sens. Environ. 1995, 54, 324-332.

58. Töyrä, J.; Pietroniro, A.; Lawrence, W.M. Multisensor hydrologic assessment of a freshwater wetland. Remote Sens. Environ. 2001, 75, 162-173.

59. Svoray, T.; Shoshany, M.; Curran, P.J.; Foody, G.M.; Perevolotsky, A. Relationship between green leaf biomass volumetric density and ERS-2 SAR backscatter of four vegetation formations in the semi-arid zone of Israel. Int. J. Remote Sens. 2001, 22, 1601-1607.

60. Baghdadi, N.; Camus, P.; Beaugendre, N.; Issa, O.M.; Zribi, M.; Desprats, J.F.; Rajot, J.L.; Abdallah, C.; Sannier, C. Estimating surface soil moisture from TerraSAR-X data over two small catchments in the Sahelian Part of Western Niger. Remote Sens. 2011, 3, 1266-1283.

61. Aubert, M.; Baghdadi, N.; Zribi, M.; Douaoui, A.; Loumagne, C.; Baup, F.; Hajj, M.E.; Garrigues, S. Analysis of TerraSAR-X data sensitivity to bare soil moisture, roughness, composition and soil crust. Remote Sens. Environ. 2011, 115, 1801-1810. 
62. Brewer, M.C.; Carter, L.D.; Glenn, R. Sudden Drainage of a Thaw Lake on the Alaskan Arctic Coastal Plain. In Proceedings of Sixth International Conference on Permafrost, Beijing, China, 5-9 July 1993; South China University of Technology Press: Guangzhou, China, 1993; Volume 1, pp. 48-53.

63. Marsh, P.; Russell, M.; Pohl, S.; Haywood, H.; Onclin, C. Changes in thaw lake drainage in the western Canadian Arctic from 1950 to 2000. Hydrol. Process. 2009, 23, 145-158.

(C) 2012 by the authors; licensee MDPI, Basel, Switzerland. This article is an open access article distributed under the terms and conditions of the Creative Commons Attribution license (http://creativecommons.org/licenses/by/3.0/). 